\title{
Autoallelopathic Potential of Leaflets and Seeds on Seedling Growth of Date Palm (Phoenix dactylifera L.)
}

\author{
M.O.A. Warrag* and A.S. Al-Wasel \\ Department of Horticulture and Forestry, College of Agriculture \\ and Veterinary Medicine, King Saud University, \\ P.O. Box 1482, Al-Qassim, Saudi Arabia
}

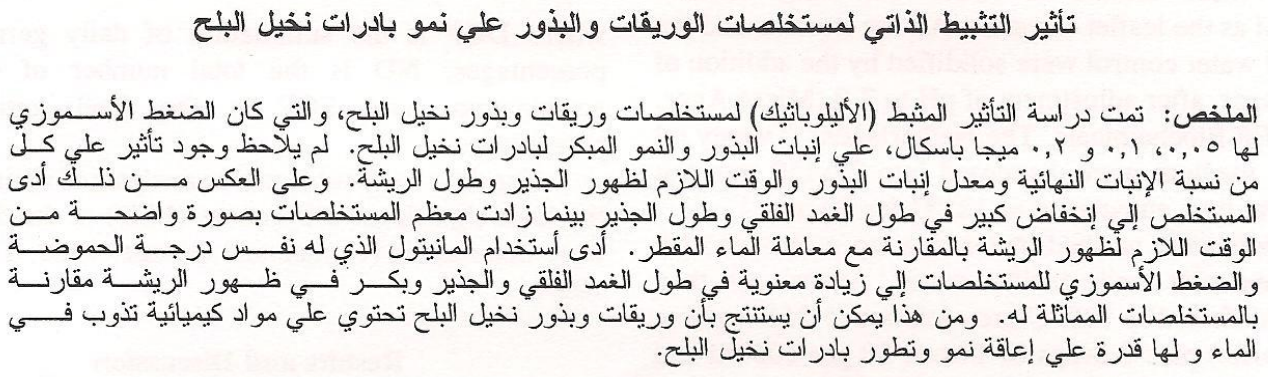

\begin{abstract}
The autoallelopathic effects of date palm leaflets and seed aqueous extracts, with $-0.05,-0.1$ and $-0.2 \mathrm{mPa}$ osmotic potentials, on seed germination and early seedling growth were investigated. Final seed germination percentage, seed germination rate, the time of radicle appearance, and plumule length were not affected. In contrast, the cotyledonary sheath and radicle lengths were significantly retarded, whereas the time of plumule appearance was significantly increased by most of the extracts in comparison with the distilled water control. Mannitol solutions, with the same osmotic potential and $\mathrm{pH}$ as the extracts, resulted in significantly longer cotyledonary sheaths and radicles and an earlier plumule appearance than their corresponding extracts. Thus, it could be deduced that date palm leaflets and seeds contain water-soluble allelochemicals that could substantially retard early seedling growth of the same species.
\end{abstract}

$\mathbf{D}^{2}$ ate palm (Phoenix dactylifera L.) is one of the most important fruit crops in the middle east and north Africa (Dowson and Aten, 1962). The common means of propagation is by offshoots. Nevertheless, the seeds are widely used in short-term studies in which seedlings are the experimental units (Al-Sewaigh et al., 1991; AlWhaibi, 1993) and for selecting clones with desirable traits.

When date palm seeds were germinated on an agar medium, it was noticed that the roots of a high percentage of the seedlings failed to elongate beyond a few millimeters, especially in the cultures having brown exudates around the roots (A.S. Al-Wasel, unpublished data). Therefore, it would appear that the aqueous extracts of date palm seeds could be inhibiting root elongation. Such an effect has been attributed to the presence of water-soluble allelochemicals (Mayer anc Polijakoff-Mayber, 1982). However, there is no information available to date concerning the nature of inhibition of root elongation in date palm. Such information should provide valuable findings that may enrich the rather limited research into the allelopathic potentials of crop germplasm (Putnam, 1986) and should add to a better understanding of this important fruit crop. This research was carried out to investigate the possible autoallelopathic effects of the leaflets and seeds on seed germination and seedling growth of date palm.

\section{Materials and Methods}

Leaflets and dry fruits of date palm cv. Ruzaiz were collected from five mature trees. Each tree was

\footnotetext{
*Corresponding author.
} 


\section{WARRAG AND AL-WASEL}

considered as a replicate. The leaflets were immediately washed with distilled water and oven-dried at $40^{\circ} \mathrm{C}$ for $72 \mathrm{~h}$. Then, they were cut into $1 \mathrm{~cm}$ long pieces and stored in polyethylene bags at room temperature. Samples of these leaflets were soaked in distilled water at the rates of 25,50 , and $100 \mathrm{~g} \mathrm{~L}^{-1}$, at $25^{\circ} \mathrm{C}$ for $24 \mathrm{~h}$. Seeds were extracted from fruits and stored in polyethylene bags at room temperature. Half $\mathrm{kg}$ of seeds per replicate were rinsed with distilled water, and then soaked in $500 \mathrm{ml}$ of distilled water for $24 \mathrm{~h}$. The mixtures of leaflets and seeds were decanted, and the liquid was filtered through Whatman No. 1 filter paper. The osmotic potentials of the leaflet extracts and a distilled water control were measured with a freezing point depression osmometer (Osmette, Model 5004, Precision System Inc., USA) (Table 1). The seed extracts were diluted to obtain the same osmotic potential as the leaflet extracts. All the extracts and the distilled water control were solidified by the addition of $7 \mathrm{~g} \mathrm{~L}^{-1}$ agar after adjustment of $\mathrm{pH}$ to 7.0 (Micro Agar, DUCHEF Biochemicals, The Netherlands). Twenty $\mathrm{ml}$ of each medium were dispensed into $25 \times 150 \mathrm{~mm}$ test tubes and then autoclaved at $121^{\circ} \mathrm{C}$ for $20 \mathrm{~min}$.

Seeds were washed in running tap water for $12 \mathrm{~h}$ and rinsed with sterile distilled water. Afterwards, they were disinfected by $10 \%$ Clorox solution ( $5.25 \%$ sodium hypoclorite) plus 2 drops of Tween 20 per $100 \mathrm{ml}$ and then rinsed three times with sterile distilled water. Each seed was placed into a test tube with the dorsal side oriented upwards (Said, 1989). Twenty test tubes were assigned per treatment per replicate in a completely randomized design inside a culture room maintained at $27 \pm 2^{\circ} \mathrm{C}$ and $16 \mathrm{~h}$ photoperiod supplied by cool white fluorescent light with 2500-3000 lux irradiance.

A second experiment was designed to determine whether the differences between the control and the extracts were due to the differences in the osmotic potentials. Hence, mannitol solutions with the same osmotic potentials as the extracts were prepared by using the following formula (Ibanze and Passera, 1997):

$$
\mathrm{W}=\frac{\mathrm{P} \mathrm{VM}}{\mathrm{RT}}
$$

where $\mathrm{W}$ is the weight of mannitol $(\mathrm{g}), \mathrm{P}$ is the desired osmotic potential (bar), $\mathrm{V}$ is the volume $(\mathrm{L}), \mathrm{M}$ is the molecular weight of mannitol $(182.17 \mathrm{~g})$, $\mathrm{R}$ is the gas constant $(0.08205)$, and $T$ is the absolute temperature $\left(\mathrm{T}={ }^{\circ} \mathrm{C}+273\right)$.

The $\mathrm{pH}$ of the extracts and the mannitol solutions were adjusted to 7.0 before the addition of the agar and then autoclaved and dispensed into test tubes as described earlier. Seeds were treated as before and a single seed was placed in each test tube. All cultures were then placed in the culture room. A split-plot design, with the osmotic potential levels as main treatments and the solutions as subtreatments, was used.

Germinated seeds were recorded daily until no further germination was observed for five successive days. A seed was considered germinated when the proximal end of the cotyledonary sheath had protruded beyond the seed coat by at least $1 \mathrm{~mm}$. The time of radicale and plumule appearance, and cotyledonary sheath, radicle, and plumule lengths were also recorded.

Seed germination percentage was determined. The corrected germination rate index (CGRI) was calculated as follows (Fulbright and Fulbright, 1990):

$$
\mathrm{CGRI}=\frac{100 \text { DGP }}{\mathrm{ND} \mathrm{FGP}}
$$

where DGP is the summation of daily germination percentages, ND is the total number of days of germination, and FGP is the final germination percentage.

The data were subjected to analysis of variance and the least significant differences (LSD) at the $5 \%$ level were determined (Gomez and Gomez, 1984; TexaSoft, 1997).

\section{Results and Discussion}

Table 1 shows that the standard errors of the means of all osmotic potential levels were very low, indicating that the replicate trees did not differ in this respect. As expected, osmotic potential levels decreased with the increase of concentration, expressed as weight of dry leaflets per liter of distilled water (Table 1). These values were significantly lower than those of the distilled water control.

The final germination percentages exhibited by the seeds cultured on extract media were as high as those exhibited by the seeds cultured on distilled water (Table 2). The same trend was also followed by the seed

TABLE 1

The osmotic potential of distilled water control and aqueous extracts of date palm leaflets.

\begin{tabular}{cc}
\hline Medium & Osmotic Potential (-mPa) \\
\hline Distilled water & 0.000 \\
Extract concentration $\left(\mathrm{g} \mathrm{L}^{-1}\right)$ & \\
25 & $0.0525^{*} \pm 0.0022$ \\
50 & $0.1324 \pm 0.0060$ \\
100 & $0.2101 \pm 0.0043$ \\
\hline
\end{tabular}

*Mean of five samples \pm standard error of the mean. 


\section{AUTOALLELOPATHIC POTENTIAL OF DATE PALM}

TABLE 2

The effect of distilled water control and aqueous extracts of date palm leaflets and seeds on seed germination and early seedling growth of date palm, three weeks from germination at $30^{\circ} \mathrm{C}$.

\begin{tabular}{|c|c|c|c|c|c|c|c|}
\hline Growth Medium & $\begin{array}{c}\text { Final } \\
\text { Germination } \\
(\%)\end{array}$ & $\mathrm{CGRI}^{1}$ & $\begin{array}{l}\text { Time for } \\
\text { Radicle } \\
\text { Appearance }\end{array}$ & $\begin{array}{l}\text { Time for } \\
\text { Plumule } \\
\text { Appearance }\end{array}$ & $\begin{array}{l}\text { Cotyledonary } \\
\text { Sheath Length } \\
(\mathrm{mm})\end{array}$ & $\begin{array}{l}\text { Radicle } \\
\text { Length } \\
(\mathrm{mm})\end{array}$ & $\begin{array}{c}\text { Plumule } \\
\text { Length } \\
\text { (mm) }\end{array}$ \\
\hline Water & 92.8 & 24.7 & 15.0 & 20.8 & 73.8 & 58.0 & 34.7 \\
\hline \multicolumn{8}{|c|}{ Leaflet extract: Osmotic potential $(-\mathrm{mPa})$} \\
\hline 0.053 & 95.2 & 25.2 & 15.4 & 22.6 & 58.2 & 28.0 & 29.9 \\
\hline 0.132 & 93.6 & 21.5 & 15.2 & 22.3 & 39.2 & 17.2 & 32.4 \\
\hline 0.210 & 94.2 & 22.7 & 15.0 & 26.8 & 10.8 & 2.8 & 36.2 \\
\hline \multicolumn{8}{|c|}{ Seed extract: Osmotic potential (-mPa) } \\
\hline 0.053 & 97.2 & 23.0 & 15.6 & 24.0 & 44.0 & 19.2 & 31.8 \\
\hline 0.132 & 92.8 & 20.3 & 14.8 & 26.0 & 43.4 & 13.2 & 33.6 \\
\hline 0.210 & 94.6 & 24.1 & 15.2 & 30.4 & 30.0 & 6.0 & 30.5 \\
\hline $\operatorname{LSD}(0.05)^{2}$ & $\mathrm{~ns}^{3}$ & ns & ns & 2.4 & 9.3 & 9.3 & ns \\
\hline
\end{tabular}

${ }^{1}$ Corrected germination rate index.

${ }^{2}$ For comparison between any two values.

${ }^{3}$ Not significant at the $5 \%$ level.

germination rate, as evaluated by the corrected germination rate index (CGRI) (Hsu et al., 1985; Fulbright and Fulbright, 1990), time from sowing to radicle appearance and the plumule length three weeks after germination (Table 2). On the other hand, there were significant differences among the treatments for each of the remaining parameters (Table 2).

Compared with the distilled water control, both leaflet and seed extracts significantly reduced the length of the cotyledonary sheath (Table 2). The length decreased with the increase of extract concentration especially in the seed extracts. Three weeks from sowing, the radicles were significantly longer in the distilled water control than in any of the extracts (Table $2)$. In fact, the radicle lengths in the distilled water control were more than double their lengths in any of the extracts. As with the cotyledonary sheath, the radicle lengths decreased progressively with the decrease of osmotic potential (Table 2). With the exception of the two least-concentrated leaflet extracts, the extracts resulted in significantly longer time from sowing to plumule appearance than the distilled water control.

To determine whether these detrimental effects would have been induced by low osmotic potentials of the extracts and/or the presence of water-soluble chemicals (Bell, 1974; Putnam, 1983; Rice, 1984) such as phytotoxins or allelochemicals, the mannitol solutions with the same osmotic potentials as the extracts were used (Table 3). Compared with the extracts, the mannitol solutions resulted in almost similar germination percentage, CGRI, time of radicle appearance, and plumule elongation rate (Table 3 ).

On the other hand, the cotyledonary sheath and the radicles were significantly longer in the mannitol solutions than in their corresponding extracts. Also, it took the plumules longer to appear in the extracts than in the mannitol solutions. Both the cotyledonary sheath and the radicle decreased in length, and the time required for plumule appearance increased progressively with the decrease of osmotic potentials of the extracts and mannitol solutions. However, these changes were proportionately far less in mannitol solutions than in the extracts, resulting in statistically significant interactions between the growth media and osmotic potential (Table 3 ). In addition, the radicle tips were brownish in color in the two higher leaflet and seed extracts. These results indicate that the osmotic potential was not totally responsible for the detrimental effects exerted by the extracts. Hence, it could be deduced that both date palm leaflets and seed extracts might have contained water soluble allelochemicals that could cause the retardation of cotyledonary sheath and radicle length and the delay of plumule appearance.

The allelochemicals were also responsible for brownish appearance of the radicle tips, a symptom that has been reported with many other plant species exposed to allelochemicals (Yang, 1982; Weston and Putnam, 1985; Warrag, 1995). The detrimental effects exerted by these allelochemicals could be due to their interference with the action of growth hormones (Geissman and Phinney, 1972), cell division (Avers and Goodwin, 1956), and/or with respiration (Demos et al., 1975). The retardation of the excised date palm root elongation in the liquid culture and its offset by charcoal (Dlaigan, 1995), might be attributed to the presence of these allelochemicals in the roots, as well. The characterization and identification of the allelochemicals will contribute to a better understanding of their 
WARRAG AND AL-WASEL

TABLE 3

The effect of mannitol solutions and aqueous extracts of date palm leaflets and seeds on seed germination and early seedling growth of date palm, three weeks from germination at $30^{\circ} \mathrm{C}$.

\begin{tabular}{|c|c|c|c|c|c|c|c|c|}
\hline $\begin{array}{c}\text { Osmotic } \\
\text { Potential } \\
(-\mathrm{mPa})\end{array}$ & Growth Medium & $\begin{array}{c}\text { Final } \\
\text { Germination } \\
(\%)\end{array}$ & $\mathrm{CGRI}^{1}$ & $\begin{array}{c}\text { Time for } \\
\text { Radicle } \\
\text { Appearance }\end{array}$ & $\begin{array}{c}\text { Time for } \\
\text { Plumule } \\
\text { Appearance }\end{array}$ & $\begin{array}{c}\text { Cotyledonary } \\
\text { Sheath Length } \\
\text { (mm) }\end{array}$ & $\begin{array}{c}\text { Radicle } \\
\text { Length } \\
(\mathrm{mm})\end{array}$ & $\begin{array}{c}\text { Plumule } \\
\text { Length } \\
\text { (mm) }\end{array}$ \\
\hline \multirow[t]{2}{*}{0.053} & Leaflet extract & 91.6 & 22.5 & 15.0 & 21.8 & 57.0 & 26.8 & 28.9 \\
\hline & Seed extract & 93.2 & 20.9 & 16.2 & 21.2 & 42.6 & 15.0 & 33.4 \\
\hline 0.132 & Manitol solution & 93.8 & 21.7 & 14.8 & 21.0 & 61.6 & 42.0 & 30.1 \\
\hline \multirow{3}{*}{0.210} & Manitol solution & 94.2 & 21.9 & 14.6 & 23.8 & 48.0 & 39.6 & 32.0 \\
\hline & Leaflet extract & 91.6 & 24.3 & 16.0 & 26.4 & 8.4 & 5.2 & 30.4 \\
\hline & Seed extract & 92.2 & 23.5 & 15.4 & 29.8 & 29.2 & 7.2 & 31.8 \\
\hline $\operatorname{LSD}(0.05)^{2}$ & & $\mathrm{~ns}^{3}$ & ns & ns & 2.1 & 7.7 & 6.9 & ns \\
\hline
\end{tabular}

${ }^{1}$ Corrected germination rate index.

${ }^{2}$ For comparison between any two values.

${ }^{3}$ Not significant at the $5 \%$ level.

mechanism(s). This should help to enrich the rather limited research into the allelopathic potentials of crop germplasm (Putnam, 1986).

\section{Conclusion}

It could be concluded from this study that date palm leaflets and seeds contain water soluble allelochemicals that could significantly retard the cotyledonary sheath and the radicle length of the seedling of the same species. In addition, the emergence of the plumule through the cotyledonary sheath was significantly delayed. The characterization and identification of these autotoxins will contribute to a better understanding of the leading fruit crop in the Arabian peninsula.

\section{References}

Al-Whaibi, M.H. 1993. Mineral content of date palm seedlings In: Proceedings of the $1^{\text {st }}$ Symposium on Date Palm, 190-195. Al-Hasna, Saudi Arabia.

Al-Sewaigh, S.M., M.H. Al-Wahibi, and M.O. Basalah. 1991 Simulation of salt strees in date palm seedlings (Phoenix dactylifera). Arab Gulf Journal of Scientific Research 9:4562.

Avers, C.J. and R.H. Goodwin. 1956. Studies on roots: IV Effects of coumarin and scopoletin on the standard root growth pattern of Phleum pratense. American Journal of Botany 43:612-620.

Dlaigan, Y.I.M. 1995. Development of a nutrient medium for the growth of date palm (Phoenix dactylifera L.) roots by tissue culture. MSc. Thesis, King Saud University, Riyadh, Saudi Arabia.

Bell, D.T. 1974. The influence of osmotic pressure in tests of allelopathy. Transactions III of the State Academy of Science 67:312-317.

Dawson, V.H.W. and A. Aten. 1962. Date handling, processing and packing. F.A.O. Agricultural Department, 72, Rome.
Demos, E.K., M. Woolwine, R.H. Wilson, and C. McMillan. 1975. The effects of ten phenolic compound on hypocotyl growth and mitochondrial metabolism of mung bean. American Journal of Botany 62:97-102.

Fulbright, N. and T.E. Fulbright. 1990. Germination of 2 legumes in Leachate from introduced grasses. Journal of Range Management 43:466-467.

Geissman, T.A. and B.O. Phinney. 1972. Tannins as gibberellin antagonists. Plant Physiology 49:323-330.

Gomez, K.A. and A.A. Gomez. 1984. Statistical Procedures for Agricultural Research ( $2^{\text {nd }}$ Edition). John Wiley, New York.

Hsu, F.H., C.L. Nelson, and A.G. Matches. 1985. Temperature effects on germination of perennial warm-season forage grasses. Crop Science 25:215-220.

Ibanze, A.N. and C.B. Passera. 1997. Factors affecting the germination of albaida (Anthyllis cytisoides L.), a forage legume of the mediterranean coast. Journal of Arid Environment 35:225-231.

Mayer, A.M. and A. Polijakoff-Mayber. 1982. The germination of seeds ( $2^{\text {nd }}$ Edition). Pergamon Press, Oxford

Putnam, A.R. 1983. Allelopathic chemicals: nature's herbicides in action. Chemical Engineering News 4:34-45.

Putnam, A.R. 1986. Allelopathy: Can it be managed to benefit horticulture? HortScience 21:411-413.

Rice, E.L. 1984. Allelopathy ( ${ }^{\text {nd }}$ Edition). Academic Press, London.

Said, A.E. 1989. The effect of seed orientation on the in vitro germination of date palm (Phoenix dactylifera L.) seeds. In: Proceedings of the $2^{\text {nd }}$ Symposium on Date Palm, 239-246. King Faisal University, Al-Hasna, Saudi Arabia.

TexaSoft. 1997. Statistical data analysis program: User's manual. TexasSoft, Cedar Hill, Texas, USA.

Warrag, M.O.A. 1995. Autotoxic potential of foliage on seed germination and early growth of mesquite (Prosopis juliflora). Journal of Arid Environment 31:415-421.

Weston, L.A. and A.R. Putnam. 1985. Inhibition of growth, nodulation, and nitrogen fixiation of legumes by quackgrass (Agropyron repens). Crop Science 25:561-565.

Yang, H.J. 1982. Autotoxicity of Asparagus officinalis L. Journal of American Society of Horticultural Science 107:860-862. 


\title{
Chromosome Characteristics of Three Date Palm Cultivars (Phoenix dactylifera L.)
}

\author{
M.A. Aly* and M.A.A. Bacha \\ Plant Production Department, College of Agriculture, King Saud University, \\ P.O. Box 2460, Riyadh 11451, Saudi Arabia
}

خصائص الكروموسومات في ثلاذية أصناف من نحيل البلج

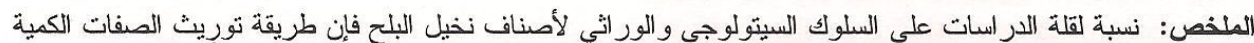

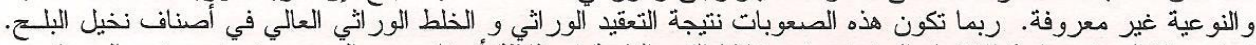

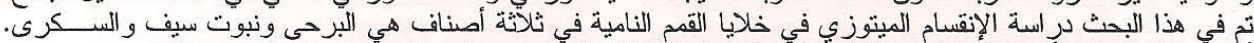

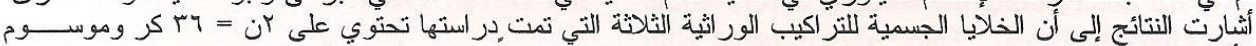

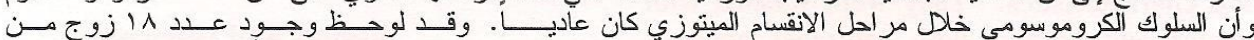

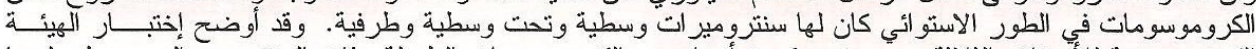

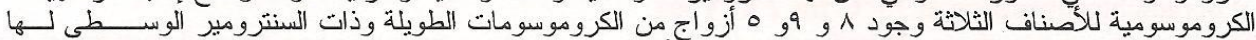

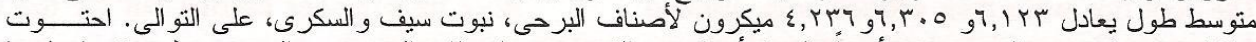

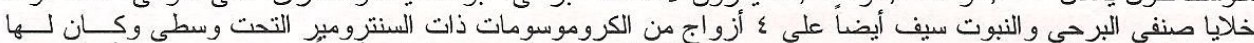

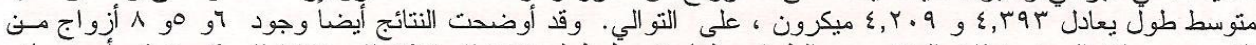

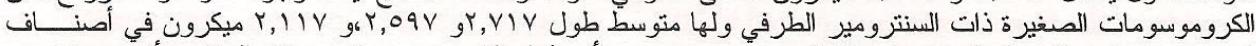

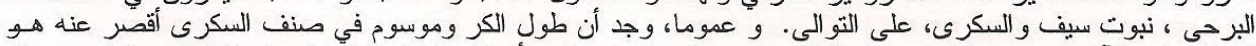

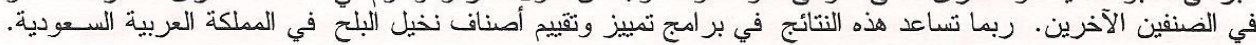

\begin{abstract}
Little is known regarding the cytogenetical behavior of different date palm cultivars. Thus, the inheritance of quantitative and qualitative characters are unknown. These difficulties may be due to the genetic complexity and high heterozygosity of date palm cultivars. Mitosis in the root tip cells of three cultivars of Barhi, Nebut Seif, and Succary were investigated in this study. Results indicated that the three genotypes studied possess the somatic number of chromosomes $(2 \mathrm{n}=36)$ and the chromosomal behavior during mitosis stages was normal. Metaphase stage in each cultivar show 18 pairs of the chromosomes $(n=18)$ having median, submedian, and terminal centromers. The karyotype examination of the chromosomes of the three cultivars revealed that 8,9 , and 5 pairs of chromosomes were long and median centromers (metacentric) with average length of $6.12,6.31$, and $4.24 \mu \mathrm{m}$ for Barhi, Nebut Seif, and Succary cultivars, respectively. Also, Barhi and Nebut Seif cultivars contained 4 pairs of chromosomes with subterminal centromers (submetacentric) with average lengths of chromosomes of 4.39 and $4.21 \mu \mathrm{m}$, respectively. The data also indicated that 6,5 , and 8 pairs of small chromosomes with terminal centromers (telocentric) were found in Barhi, Nebut Seif, and Succary cultivars, respectively. The chromosome length of the Succary cultivar was generally shorter than those of the Barhi and Nebut Seif cultivars. These results may be helpful in the program of identification and evaluation of date palm cultivars grown in Saudi Arabia.
\end{abstract}

T There is a general lack of cytogenetical studies of different date palm cultivars. Such information is helpful when breeding for date improvement and in resolving problems about identification and classification of palm cultivars. These difficulties may be due to the genetic complexity and the high heterozygosity of date cultivars. Because of the small size of the chromosomes that range between 1 and $4 \mu \mathrm{m}$ (Soliman and Al-Mayah, 1978), the high somatic number of the chromosomes, and the lack of genetic markers in date cultivars, it is difficult to identify individual pairs of chromosomes and to prepare a

${ }^{*}$ Corresponding author. 


\section{ALY AND BACHA}

karyotype of date cultivars. Moreover, Siljak et al. (1996) stated that greater evaluation and manipulation of genetic diversity within the Phoenix gene pool is urgently needed for sustainable production, species conservation, and environmental preservation. Also, they reported that the cytological markers of sex in Phoenix provide tools for genetic programs. Chromosome number and characteristics were studied to help in identification and classification of date palm cultivars and to provide information for breeding programs.

\section{Materials and Methods}

Ripe date palm fruits were collected from mature bunches on trees of Barhi, Nebut Seif, and Succary cultivars. Seeds from the three genotypes were extracted and soaked in distilled water for $72 \mathrm{~h}$ then germinated in the greenhouse using a perlite medium. Root tips of seedlings (about $1 \mathrm{~mm}$ long) were excised after 30 days for determining the somatic chromosome number and characteristics. They were washed with distilled water and treated with saturated aqueous solution of paradichlorobenzene at $15^{\circ} \mathrm{C}$ for $2 \mathrm{~h}$ (Vosa, 1976). The root tips were then washed with distilled water and placed in Carnoy's fluid (95\% ethanol: glacial acetic acid, $3: 1 \mathrm{v} / \mathrm{v}$ ) for $48 \mathrm{~h}$ at room temperature. Tips were removed from the fixative solution, placed in $70 \%$ ethanol, and stored in a refrigerator $\left(4^{\circ} \mathrm{C}\right)$ until used.

In preparation for staining, root tips were removed from the $70 \%$ ethanol, washed with distilled water, and hydrolyzed for 15 to $20 \mathrm{~min}$ in $1 \mathrm{~N}$ hydrochloric acid at $60^{\circ} \mathrm{C}$ (Okolo, 1988). The acid was then removed and the roots were rinsed with distilled water and placed in $2 \%$ acetocarmine stain in covered vials for 1 to $1.5 \mathrm{~h}$. Finally, the tips were placed on a slide in a drop of acetocarmine and the unstained root cap was removed with a razor blade and discarded. The tip was tapped gently but thoroughly with a glass rod, a cover-slip was applied, and the slide was warmed and firmly pressed under filter paper to get maximum spread of chromosomes. Slides were examined soon after preparation under high power objectives and the details of chromosomes were studied under oil immersion objective (1500x).

In all genotypes studied, counts and lengths were made from at least 10 slides using an ocular micrometer. Counts and lengths were taken in the three date palm cultivars in the metaphase stage. All measurements are expressed in microns using a plate micrometer. The chromosomes were classified according to the position of the centromere (Levan et al., 1964). The results of chromosome counting, lengths, and classification of the three date palm cultivars were statistically analyzed for variance using a completely randomized design. Least

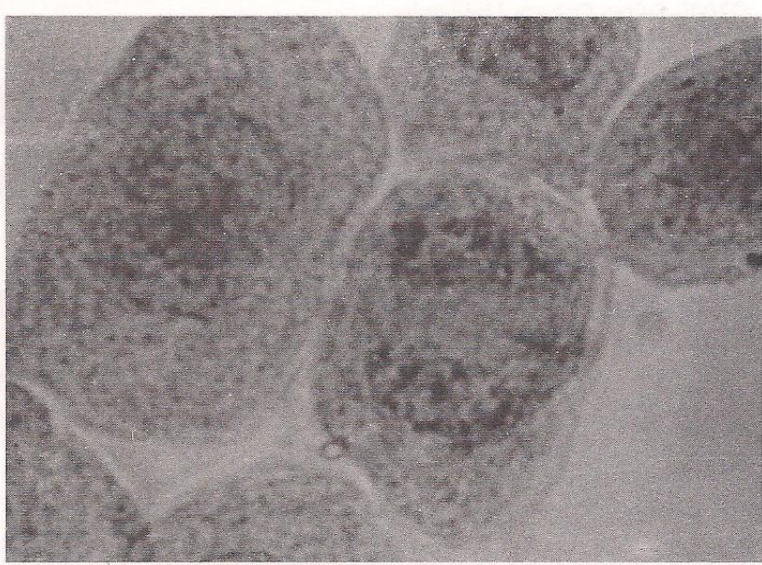

Figure 1. Mitotic metaphase and anaphase stages in date palm $(\mathrm{n}=18)$.

significant difference was used to compare means (Steel and Torrie, 1981).

\section{Results and Discussion}

Root tip squashes carried out for the three date palm cultivars (Barhi, Nebut Seif, and Succary) revealed that mitosis was normal for three genotypes. All three cultivars studied possess the somatic chromosome number, $2 n=36$ with 18 pairs of homologous chromosomes (Figure 1). In this matter, these observations agree with the results of Venkatasubban (1945), Darlington and Wylie (1955), Murin and Chaudhri cited after Love (1970), Soliman and AlMayah (1978), A1-Salih et al. (1987), and Shaheen and Youssef (1990). They stated that all stages of the mitosis in date palm were normal. Sharma and Sarkar (1956) observed that there is apparent homogeneity in chromosome number in different species of the same genus in the tribe, Calameae, of the Palmae. Moreover, Salman et al. (1988) reported that the number of chromosomes in all studied samples of 7 cultivars was 36 and this indicates that all cultivars studied were diploid and that a good chromosomal stability exists in date palm. Al-Salih et al. (1987) reported clear differences in chromosome number among cultivars, in Sayer $(2 n=32)$ and Khsab $(2 n=36)$. They found that in addition to these differences aneuploidy and euploidy has been observed within the same cultivar; the chromosome number in Sayer was $(32,34,36$, and 64) and in Khsab (32 and 36).

The results of the present study indicated that the chromosomes of the three date cultivars have long chromosomes with metacentric centromers, medium chromosomes with submetacentric centromers, and small chromosomes with telocentric centromers. The 


\section{CHROMOSOME CHARACTERISTICS OF THREE DATE PALM CULTIVARS}

TABLE 1

Characteristics of metacentric chromosomes in three date palm cultivars.

\begin{tabular}{ccccc} 
Cultivars & $\begin{array}{c}\text { Chromosome } \\
\text { Length } \\
(\mu \mathrm{m})\end{array}$ & $\begin{array}{c}\text { Right } \\
\text { Arm } \\
(\mathrm{R})\end{array}$ & $\begin{array}{c}\text { Left } \\
\text { Arm } \\
(\mathbf{L})\end{array}$ & $\begin{array}{c}\text { R/L } \\
\text { Ratio }\end{array}$ \\
\hline Barhi & $6.123 \mathrm{a}$ & $3.089 \mathrm{a}$ & $3.067 \mathrm{a}$ & $1.007 \mathrm{a}$ \\
Nebut Seif & $6.353 \mathrm{a}$ & $3.172 \mathrm{a}$ & $3.178 \mathrm{a}$ & $0.998 \mathrm{~b}$ \\
Succary & $4.236 \mathrm{~b}$ & $2.093 \mathrm{~b}$ & $2.112 \mathrm{~b}$ & $0.991 \mathrm{c}$
\end{tabular}

Means not sharing the same letter within columns are significantly different $(\mathrm{P}<0.05)$.

karyotype examination of the chromosomes in the three date palm cultivars revealed 8,9 , and 5 pairs of long and metacentric centromers; 4,4 , and 5 pairs of medium and submetacentric centromers; and 6, 5, and 8 pairs of small and telocentric centromers for Barhi; Nebut Seif; and Succary cultivars, respectively. Soliman and Al-Mayah (1978), Shaheen and Youssef (1990), and Selbi and Al-Rubeaa (1992) reported that the consistency of chromosome length and position of the centromer in each cultivar may indicate that sex determination in date palm is genetically controlled rather than being controlled by chromosomal behavior. Okolo (1988), working on six species of Raphia palms, found marked differences in the chromosome length in each species and chromosomes which were classified as short had medium constrictions, while medium and long chromosomes included metacentric, submetacentric, and acrocentric centromers. Al-Salih and Al-Rawi (1987), working on two date palm cultivars, found that karyotype analysis revealed asymmetrical types in both cultivars. The determined chromosome length was between 0.99 and $2.55 \mu \mathrm{m}$ for Lilwi, and 0.74 to 2.38 $\mu \mathrm{m}$ for Ashgar. In the former, eight chromosomes are achrocentric, while the number of chromosomes of such type is 10 in the latter.

Data in Tables 1 to 3 reveal that chromosome length measured by the acetocarmine method in the three cultivars varied from 2.117 to $6.253 \mu \mathrm{m}$.

TABLE 2

Characteristics of submetacentric chromosomes in three date palm cultivars.

\begin{tabular}{ccccc} 
palm cultivars. & $\begin{array}{c}\text { Chromosome } \\
\text { Length } \\
(\mu \mathrm{m})\end{array}$ & $\begin{array}{c}\text { Right } \\
\text { Arm } \\
(\mathrm{R})\end{array}$ & $\begin{array}{c}\text { Left } \\
\text { Arm } \\
(\mathrm{L})\end{array}$ & $\begin{array}{c}\text { R/L } \\
\text { Ratio }\end{array}$ \\
\hline Barhi & $4.393 \mathrm{a}$ & $2.893 \mathrm{a}$ & $1.477 \mathrm{a}$ & $1.959 \mathrm{~b}$ \\
Nebut Seif & $4.209 \mathrm{a}$ & $2.900 \mathrm{a}$ & $1.331 \mathrm{a}$ & $2.178 \mathrm{~b}$ \\
Succary & $2.920 \mathrm{~b}$ & $2.052 \mathrm{~b}$ & $0.904 \mathrm{~b}$ & $2.270 \mathrm{a}$ \\
\hline
\end{tabular}

Means not sharing the same letter within columns are significantly different $(\mathbf{P}<0.05)$.
TABLE 3

Characteristics of telocentric chromosomes in three date palm cultivars.

\begin{tabular}{ccccc}
\hline Cultivars & $\begin{array}{c}\text { Chromosome } \\
\text { Length } \\
(\mu \mathrm{m})\end{array}$ & $\begin{array}{c}\text { Right } \\
\text { Arm } \\
(\mathrm{R})\end{array}$ & $\begin{array}{c}\text { Left } \\
\text { Arm } \\
(\mathrm{L})\end{array}$ & $\begin{array}{c}\text { R/L } \\
\text { Ratio }\end{array}$ \\
\hline Barhi & $2.716 \mathrm{a}$ & $-\cdots$ & $-\cdots$ & $-\cdots$ \\
Nebut Seif & $2.597 \mathrm{a}$ & $-\cdots$ & $-\cdots$ & --- \\
Succary & $2.117 \mathrm{~b}$ & $-\cdots$ & $-\cdots$ & ---
\end{tabular}

Means not sharing the same letter within columns are significantly different $(\mathbf{P}<0.05)$

Chromosomes above $5.0 \mathrm{~m}$ were regarded as long, 3.0 to $5.0 \mu \mathrm{m}$ as medium, and below $3.0 \mu \mathrm{m}$ as short. The data showed that Nebut Seif cultivar had the longest chromosome length $(6.353 \mu \mathrm{m})$ with a $\mathbb{R} / \mathrm{L}$ ratio of 0.998 , followed by Barhi cultivar $(6.123 \mu \mathrm{m})$ with a $1.007 \mathrm{R} / \mathrm{L}$ ratio, while Succary cultivar recorded the shortest length $(4.236 \mu \mathrm{m})$ with a $0.991 \mathrm{R} / \mathrm{L}$ ratio. Mean length of medium chromosomes with submetacentric centromeres were 4.393, 4.209, and $2.920 \mu \mathrm{m}$ in Barhi, Nebut Seif, and Succary cultivars, respectively. The length of the right and left arms of chromosomes were significantly lower in the Succary cultivar compared to the Barhi and Nebut Seif cultivars. No significant differences were found between Barhi and Nebut Seif cultivars in length of right and left arms of chromosomes. Also, a significant difference was found among the three cultivars in the ratio of $\mathrm{R} / \mathrm{L}$ metacentric chromosomes, and between Succary and the other two cultivars in the $\mathrm{R} / \mathrm{L}$ ratio for submetacentric chromosomes. The above results of chromosome characteristics for three date palm cultivars may suggest a method for identification and classification of cultivars.

\section{Conclusion}

The cytogenetical behavior of three date palm cultivars were investigated in this study along with the mitosis in the root tip cells of the cultivars. Results indicated that the three genotypes studied possess the somatic number of chromosomes $(2 \mathrm{n}=36)$ and the chromosomal behavior during mitosis stages was normal. Metaphase stage in each cultivar show 18 pairs of the chromosomes having median, submedian, and terminal centromers. The chromosome length of the Succary cultivar was generally shorter than those of the Barhi and Nebut Seif cultivars. These results may be helpful in the identifying and evaluating the date palm cultivars grown in Saudi Arabia. 


\section{ALY AND BACHA}

\section{References}

Al-Salih, A.A. and A.M.A. Al-Rawi. 1987. A study of cytology of two female cultivars of date palm. Date Palm Journal $5(2): 134-142$.

Al-Salih, A. A., N. Hussain, and A. Al-Jarrah. 1987. Chromosomes number of a date palm: cultivar Ghannami Akhdar. Date Palm Joumal 5(2):128-133.

Darlington, C.D. and A.P. Wylie. 1955. Chromosome Atlas of Flowering Plants. Allen and Union Ltd, London.

Levan, A., K. Fredga, and A.A. Sandberg. 1964. Nomenclature for centromeric position on chromosomes. Heriditas 52:201220.

Love, A. 1970. Chromosome number reports. International Organization of Plant Breeding and Taxonomy 19:264-269.

Okolo, A. 1988. Chromosome counts on Nigerian species of the genus raphia. Princips 32:156-159.

Salman, R.M., A.A.M. Al-Jiboury, W.K. Al-Quadhy, and M.S. Omar. 1988. Isozyme and chromosomal analysis of tissue culture derived date palms. Date Palm Journal 6(2):401-411.

Selbi, M.I. and A.L. Al-Rubeaa. 1992. Cytogenetic studies and microsporogensis of date palm Phoenix dactylifera $\mathrm{L}$. The Nucleus 35:176-179.
Shaheen, M.A. and M.K. Youssef. 1990. Karyological study of "Khudari" date palm (Phoenix dactylifera L.) seedlings chromosomes. Journal of King Abdulaziz University: Arid Land Agricultural Science 1:77-82.

Sharma, A.K. and K.S. Sarkar. 1956. Cytology of different species of palms and its bearing on the solutions of the problems of phylogeny and speciation. Genetica 28:361-488.

Siljak, S., S. Yakovlev, M. Benmalek, T. Cerbah, P. Coba, N. Bounaga, C. Brown, and A. Sarr. 1996. Chromosomal sex determination and heterochromatin structure in date palm. Sex Plant Report 9:127-132.

Soliman, A.S. and A.A. Al-Mayah. 1978. Chromosome studies in date palm Phoenix dactyiifera L. Microscopica Acta 80 (2): $145-148$.

Steel, R.G. and J.H. Torrie. 1981. Principles and Procedures of Statistics. McGraw-Hill Publishing Co., New York, U.S.A.

Venkatasubban, K.R. 1945. Cytological studies in palmae: Part I. Chromosome number in a few species of palms of British India and Ceylon. Proceedings of the Indian Academy of Science, Section B, 22:193-207.

Vosa, S.C. 1976. Heterochromatin classification in Vicia faba and Scilla sibirica. Chromosomes Today 5:185-192. 